\title{
Spectrophotometric Study of the Reaction between Tryptophan and Ferroin at Different Forms
}

\author{
M.A. Zayed ${ }^{\#}$ and M.M. Taha* \\ Chemistry Department, Faculty of Science, Cairo University \\ and "Adam International Hospital, Mohandeseen, Giza, Egypt.
}

\begin{abstract}
7 HE INDICATOR ferroin III had been prepared by titration of Ferroin II against permanganate in sulfuric acid medium till blue color appeared of $\lambda_{\max }=590 \mathrm{~nm}$. The effect of time on the stability of blue ferroin (III) at $\lambda_{\max }=590 \mathrm{~nm}$ was studied and it was found to completely change into red ferroin (II) of $\lambda_{\max }=515 \mathrm{~nm}$ within $3 \mathrm{hr}$. Therefore, in this study the redox reaction between tryptophan (Trp) and ferroin indicator in its oxidized form (ferroin III) had been carefully studied; aiming to use both forms of this indicator in spectrophotometric micro-determination of Trp in pure form and in embryo synthetic and actual media. It had been found that; at $\lambda_{\max }=$ $590 \mathrm{~nm}$ the reaction between Trp and ferroin III involved oxidation of Trp into $\operatorname{Trp}^{-}$and the indicator spontaneously reduced to ferroin II. Tracing the reaction between two forms of ferroin indicator after adding variable $[\mathrm{Trp}]=10^{-3} \mathrm{M}$ under proper selected conditions leads to the construction of two linear calibration curves, descending at $\lambda_{\max }=590 \mathrm{~nm}$ and ascending at $\lambda_{\max }=515 \mathrm{~nm}$. This means that the reaction at $\lambda_{\max }=590 \mathrm{~nm}$ is a redox reaction and at $\lambda_{\max }=515 \mathrm{~nm}$ may be ion-pair formation [Trp] $\left[\right.$ ferroin] ${ }^{++}$. The concentration ranges of the two calibration graph are found to be 2.05997-12.3594 and $41.058-164.2 \mu \mathrm{g} \mathrm{mL}^{-1}$, respectively and the linearity was satisfactory $(r=0.9991$ and $r=0.999$, respectively). The methods are successfully applied to a synthetic mixture containing some components of the human embryos' culture medium without interference and the results are satisfactory. This encouraged us to apply these procedures to the actual culture medium which yield a percent recovery of Trp in this medium of $99.51-101.5$ and $100.2-100.3 \%$ at $\lambda=515$ and $590 \mathrm{~nm}$, respectively and with $\mathrm{SD}=0.003464-0.01963$ and $\mathrm{RSD}=0.1640$ 0.3679 and Sandell sensitivity of $S\left(\mu \mathrm{g} \mathrm{cm} \mathrm{cm}^{-2}\right)=7.424 \times 10^{-7}$. These values refer to the accuracy and precision of the applied spectrophotometric procedures in embryo media analyses. The importance of this research work stems from; it is the first time to find cheap, simple and rapid spectrophotometric methods for Trp analyses that present in synthetic and actual embryo medium constituents. These methods can be used as alternative for expensive sophisticated tools such as HPLC, HNMR and mass famously used in literature.
\end{abstract}

Keywords: Ferroin indicator, Redox reaction, Ion-pair formation, Microdetermination of Trp and Analyses of embryo culture medium.

${ }^{\#}$ Corresponding author: Tel. 01005776675, Office Tel.3567662;

e-mail: mazayed429@yahoo.com 
Tryptophan is one of the culture medium components employed for clinical IVF to support development of human embryo in vitro. Studies on the embryos of several mammalian species such as mouse, hamster, sheep and cows, have all demonstrated that the inclusion of specific amino acids in the culture medium enhances embryo development to the blastocyst stage ${ }^{(1-11)}$. A number of the quantitative techniques that can monitor the uptake of specific nutrients by the embryo from the surrounding medium and detect the secretion of specific metabolites and factors are now being optimized to measure such changes in culture media ${ }^{(12)}$. The assessment tool must fulfil a number of criteria so that they can be applicable in IVF clinics. To be applied in clinical IVF, tools must have the ability to measure change without damaging the embryo, the ability to measure changes quickly and the ability to measure changes consistently and accurately.

\section{Experimental}

\section{Materials and reagents}

All chemicals were of the highest purity available. They included tryptophan (Trp) provided by WINLAB, UK; glucose provided by El Nasr Pharmaceutical Chemicals Co., Egypt and Sulfuric acid was supplied from Analytical Rasayan. Glycine (Gly) and potassium permanganate were purchased from ADWIC. Potassium chloride and sodium pyruvate were supplied from MERCK, Germany. Sodium bicarbonate was provided by El Gomhouria Co. Egypt.

The reagent used was 1, 10- phenanthroline iron (II) sulfate complex (ferroin) from FLUKA.

\section{Solutions}

$2.017 \times 10^{-4} \mathrm{M}$ solution of Trp was prepared by dissolving $0.0103 \mathrm{~g}$ in $250 \mathrm{ml}$ distilled water; $\mathrm{NaHCO}_{3}$ was added as $0.0042 \mathrm{~g} / 250 \mathrm{ml}$.

$5 \times 10^{-4} \mathrm{M}$ ferroin (II) indicator solution was prepared by the appropriate dilution of conc. $0.025 \mathrm{M}$ original solution by distilled water. Ferroin (III) oxidant indicator was freshly prepared, in each experiment, by titration of Ferroin (II), in $0.3 \mathrm{~N}$ sulfuric acid medium, against standard $5.247 \times 10^{-4} \mathrm{M}$ permanganate.

Potassium permanganate was prepared by dissolving $0.0207 \mathrm{~g}$ in $250 \mathrm{ml}$ distilled water. $2.036 \times 10-3 \mathrm{M}$ sodium pyruvate $(\mathrm{C} 3 \mathrm{H} 3 \mathrm{NaO} 3,110.044 \mathrm{~g} / \mathrm{mol}$.) and1.0028x 10-2 M Gly $\left(\mathrm{NH}_{2} \mathrm{CH}_{2} \mathrm{COOH}\right.$, Molar mass: $75.0666 \mathrm{~g} / \mathrm{mol}$., $\mathrm{C} 2 \mathrm{H} 5 \mathrm{NO} 2$ ) were prepared by dissolving the accurately weighed amount in an accurate volume of distilled water to get the required concentration. Diluted solutions were prepared by accurate dilution from the stock solution to get the desired concentrations. Solutions were protected from light by keeping them in dark colored quick fit bottles during the whole work. $3.024 \mathrm{~N}$ sulfuric has been prepared by dilution from conc. acid $(36 \mathrm{~N}) .1 .003 \times 10^{-1} \mathrm{M}$ stock solution of sodium bicarbonate and $1.002 \times 10^{-1} \mathrm{M}$ stock solution of $\mathrm{KCl}$ were prepared by dissolving $2.106 \mathrm{~g}$ and $1.868 \mathrm{~g}$ of each respectively in $250 \mathrm{ml}$ of distilled water.

Egypt. J. Chem. 58, No. 3 (2015) 
Equipment

The spectrophotometric measurements were carried out using the automatic optizen pop spectrometer (Mecasys Co., Ltd/ made in Korea) in the wavelength range region from $200-800 \mathrm{~nm}$ and quartz cell of $1 \mathrm{~cm}$ optical length was used. Small volumes were taken using automatic pipettes (Accupipet, USA) (0.01-1.0 $\mathrm{ml})$. Weights measurement was performed by using Radwag wagi Elektroniczne Sensitive analytical balance $0.0001 \mathrm{~g}$, Model: AS 220/C/1. Water used in the research was obtained by distillation from all glass equipment. All glassware used were washed carefully with distilled water and dried in the oven before use.

\section{Methods}

Preparation of FERR (III) oxidant indicator

Ferroin (III) oxidant indicator (FERR III) had been freshly obtained by direct titration of $0.025 \mathrm{M}$ Ferroin (II) (FERR II) in $0.3 \mathrm{~N}$ sulfuric acid medium against standard potassium permanganate. Freshly prepared FERR (III) was used during all experimental parts.

Selection of the suitable wavelengths (גmax) of FERR (II) and FERR (III) at different conditions

To obtain $2.5 \times 10^{-3} \mathrm{M}$ FERR (III) complex oxidant form, $1 \mathrm{ml}$ of $2.5 \times 10^{-2} \mathrm{M}$ FERR (II) indicator was transferred to a $10 \mathrm{ml}$ volume measuring flask followed by addition of $1 \mathrm{ml}$ of $3.024 \mathrm{~N} \mathrm{H}_{2} \mathrm{SO}_{4}$. This mixture had been carefully titrated against $\mathrm{KMnO}_{4}\left(1.215 \times 10^{-3} \mathrm{M}\right)$ until the formation of a blue color is reached at end point and complete the volume with distilled water. The absorption spectrum of FERR (III) was scanned against water in the wavelength region 400-765 $\mathrm{nm}$. From the data obtained,$\lambda_{\max }$ of ferroin in the oxidized form was determined and found to be 590 $\mathrm{nm}$. The FERR (III) solution stability was affected by time and temperature.

Effect of time on FERR (III) spectra

The effect of time on absorbance of freshly prepared $2.5 \times 10^{3-} \mathrm{M}$ FERR (III) oxidant solution in $1 \mathrm{ml} 3.024 \mathrm{~N}$ sulfuric acid; in $10 \mathrm{ml}$ measuring flask was measured at different time intervals ranged from 0 to $180 \mathrm{~min}$. The absorbance values obtained in the wavelength range 400-700 $\mathrm{nm}$ were measured. The absorbance values obtained were plotted against time to check stability of FERR (III) indicator at this time interval. It was found that FERR (III) changed completely to FERR (II) in sulfuric acid medium after $3 \mathrm{hr}$ at room temperature; it had $\lambda_{\max }=515 \mathrm{~nm}$.

Spectrophotometric study of the redox reaction between tryptophan (Trp) and ferroin indicator (FERR) in its different forms (FERR II and FERR III)

a. Stoichiometry of the reaction between ferroin (III) and Trp: The stoichiometric study of the reaction between ferroin (III) and Trp had been done by molar ratio method $(\mathrm{mrm})$; in which different volumes $(0.5-5.5 \mathrm{ml})$ of $\left(1.01199 \times 10^{-3} \mathrm{M}\right)$ Trp were added to $2.5 \mathrm{ml}$ of $\left(1 \times 10^{-3} \mathrm{M}\right.$ (FERR) III (in sulfuric acid medium in $10 \mathrm{ml}$ measuring flask. The absorbance values were measured at $\lambda_{\max }=590 \mathrm{~nm}$ and at normal temperature within 10-15 min. These values were plotted against [Trp] / [FERRIII] ratio from which 1:1 ratio had been detected . 
b. Effect of variable concentration of Trp on spectra of FERR (III) reaction product at $\lambda \max =590 \mathrm{~nm}$ : To $1.0 \mathrm{ml}$ of $\left(2.5 \times 10^{-2} \mathrm{M}\right)$ of freshly prepared FERR (III) in $10 \mathrm{ml}$ measuring flask; 0.2 to $0.8 \mathrm{ml}$ of $1.0052 \times 10^{-2} \mathrm{M}$ Trp were added in $1 \mathrm{ml} 3.024 \mathrm{~N}$ sulfuric acid medium. The absorbance values were measured at $\lambda_{\max }=590 \mathrm{~nm}$ at normal temperature within $10-15 \mathrm{~min}$. These absorbance values were plotted against [Trp] and found to be linear descending relation. This may be related to reduction of FERR (III) to FERR (II) and oxidation of Trp. This linear descending calibration curve can be used in Microdetermination of Trp via redox reaction with FERR (III) at $\lambda_{\max }=590 \mathrm{~nm}$ and normal temperature.

c. Effect of time on reaction between FERR (III) and Trp : In $10 \mathrm{ml}$ volume measuring flask, $1 \mathrm{ml}$ of $\left(1 \times 10^{-3} \mathrm{M}\right)$ FERR (III) and $10 . \mathrm{ml}\left(1.0047 \times 10^{-3} \mathrm{M}\right)$ of Trp were mixed in in $1 \mathrm{ml} 3.024 \mathrm{~N}$ sulfuric acid medium and absorbance values were measured at different time intervals to $135 \mathrm{~min}$ at normal temperature. From obtained data it appears at $\lambda_{\max }=515 \mathrm{~nm}$. This means that; the reaction product changes its nature from blue form $\left(\lambda_{\max }=590 \mathrm{~nm}\right)$ into brown form $\left(\lambda_{\max }=515\right.$ $\mathrm{nm})$.

d. Validity of beer's law of reaction between standard Trp in its oxidized form and ferroin (II) reduced form at $\lambda \max =515 \mathrm{~nm}$ : Different volumes $(0.5-3.5 \mathrm{ml})$ of $\operatorname{Trp}\left(2.0173 \times 10^{-4} \mathrm{M}\right)$ were added to $4 \mathrm{ml}$ of FERR III $\left(5 \times 10^{-4} \mathrm{M}\right)$ in $1 \mathrm{ml} 3.024$ $\mathrm{N}$ sulfuric acid medium in $10 \mathrm{ml}$ capacity measuring flask. The absorbance values of these mixtures were measured after $30 \mathrm{~min}$ at $\lambda_{\max }=515 \mathrm{~nm}$ against water as a blank. These values were plotted against [Trp] to give ascending calibration curve that can be used in micro-determination of Trp in its oxidized form via reaction with FERR (II) obtained reduced form.

The obtained calibration curves of standard Trp on reaction with both FERR (III) at $\lambda_{\max }=590 \mathrm{~nm}$ and with FERR (II) at $\lambda_{\max }=515 \mathrm{~nm}$ can be used in microdetermination of Trp in synthetic and actual embryo culture medium.

Microdetermination of Trp in synthetic and actual embryo culture medium at $\lambda_{\text {max }}=590$ and $515 \mathrm{~nm}$

Before going to determine Trp in embryo's culture medium interference of other constituents should be studied, at both $\lambda_{\max }=590$ and $515 \mathrm{~nm}$. Synthetic mixture components that were analyzed at $\lambda_{\max }=590$ are given in Table 1 and that analyzed at $\lambda_{\max }=515 \mathrm{~nm}$ is given in Table 2 .

a. Interference study of embryo's culture medium constituents on the accuracy of the proposed procedure at $\lambda_{\max }=590 \mathrm{~nm}$ : Different volumes $(0.2-2.0 \mathrm{ml})$ of synthetic embryo medium mixture (Table 7) were added to $1.0 \mathrm{ml}$ of FERR III $\left(2.5 \times 10^{-2} \mathrm{M}\right)$ in $1.0 \mathrm{ml} 3.024 \mathrm{~N}$ sulfuric acid medium and the volume was completed to $10 \mathrm{ml}$ by distilled water and absorbance was measured within 10 $\min$ at $\lambda_{\max }=590 \mathrm{~nm}$ and at normal temperature. The concentration of Trp each mixture was calculated from previously constructed calibration curve at $\lambda_{\max }=$ $590 \mathrm{~nm}$ and at normal temperature. The data obtained was used to check the Egypt. J. Chem. 58, No. 3 (2015) 
effect of the other constituents of embryo medium on accuracy for determination of Trp in this medium via redox reaction with FERR (III).

TABLE 1. The composition of the synthetic mixture used for interference study at $\lambda_{\max }=590 \mathrm{~nm}$.

\begin{tabular}{|l|c|}
\hline Component & Weight taken $(\mathbf{g} / \mathbf{2 5 0} \mathbf{~ m l})$ \\
\hline Trp & 0.2203 \\
\hline $\mathrm{NaHCO}$ & 0.0894 \\
\hline Gly & 0.0757 \\
\hline Sodium pyruvate & 0.1131 \\
\hline glucose & 0.1820 \\
\hline $\mathrm{KCl}$ & 0.0833 \\
\hline
\end{tabular}

b. Interference study of embryo's culture medium constituents on the accuracy of the proposed procedure at $={ }_{\max } \lambda 515 \mathrm{~nm}$ : Different volumes $(0.5-3.5 \mathrm{ml})$ of synthetic embryo medium mixture (Table 2) were added to $4 \mathrm{ml}$ of FERR III $\left(5 \times 10^{-4} \mathrm{M}\right)$ in $1.0 \mathrm{ml} 3.024 \mathrm{~N}$ sulfuric acid medium and the volume was completed to $10 \mathrm{ml}$ by distilled water and absorbance was measured within 30 $\min$ at $\lambda_{\max }=515 \mathrm{~nm}$ and at normal temperature. The concentration of Trp each mixture was calculated from previously constructed calibration curve at $\lambda_{\max }=$ $515 \mathrm{~nm}$ and at normal temperature. The data obtained was used to check the effect of the other constituents of embryo medium on accuracy for determination of Trp in this medium via interaction with FERR (II).

TABLE 2. The composition of the synthetic mixture used for interference study at $\lambda_{\max }=515 \mathrm{~nm}$.

\begin{tabular}{|l|c|}
\hline Component & Weight taken $(\mathbf{g} / \mathbf{2 5 0}$ ml) \\
\hline Trp & 0.0109 \\
\hline $\mathrm{NaHCO}_{3}$ & 0.0046 \\
\hline Gly & 0.0056 \\
\hline Sodium pyruvate & 0.0059 \\
\hline glucose & 0.0931 \\
\hline $\mathrm{KCl}$ & 0.0037 \\
\hline
\end{tabular}

Microdetermination of Trp in the actual embryo culture medium using $2.5 \times 10^{-2} M$ ferroin at $\lambda_{\text {max }}=590 \mathrm{~nm}$

Different volumes of the human embryo's culture media $(1.5-3 \mathrm{ml})$ were added to $1.0 \mathrm{ml}$ of FERR III $\left(2.5 \times 10^{-2} \mathrm{M}\right)$ and $1.0 \mathrm{ml} 3.024 \mathrm{~N}$ sulfuric acid medium and the mixture was completed with distilled water to $10 \mathrm{ml}$ capacity in measuring flask. This procedure was repeated five times. The absorbance values were measured at $\lambda_{\max }=590 \mathrm{~nm}$ against distilled water as a blank. The concentration of Trp in this actual medium had been calculated from previously constructed calibration curve under the same conditions. 
Microdetermination of Trp in the actual embryo culture medium using $1 \times 10^{-4}$ $M$ ferroin at $\lambda_{\max } 515 \mathrm{~nm}$

Two different volumes of the human embryo's culture media were added to $4 \mathrm{ml}$ of FERR III $\left(2.5 \times 10^{-4} \mathrm{M}\right)$ in $1.0 \mathrm{ml} 3.024 \mathrm{~N}$ sulfuric acid medium and the mixture was completed with distilled water to $10 \mathrm{ml}$ capacity in measuring flask. This mixture was repeated five replicates. The absorbance values were measured at $\lambda_{\max }=515 \mathrm{~nm}$ within $30 \mathrm{~min}$ against distilled water as a blank. The concentration of Trp in this actual medium had been calculated from previously constructed calibration curve under the same conditions.

\section{Results and Discussion}

Selection of the suitable wavelength of ferroin indicator $\left(\lambda_{\max }\right)$ at different conditions

The absorption spectrum of $2.5 \times 10^{-4} \mathrm{M}$ ferroin (II) indicator solution which is red in color was scanned in the wavelength region 400-800 $\mathrm{nm}$ against distilled water as a blank. The data obtained are represented in Fig. 1. It is clear from these results that $\lambda \max$ of the indicator occurs at $510-515 \mathrm{~nm}\left(\varepsilon=1.0184 \times 10^{4}\right.$ $\mathrm{Lmol}^{-1} \mathrm{~cm}^{-1}$ ).

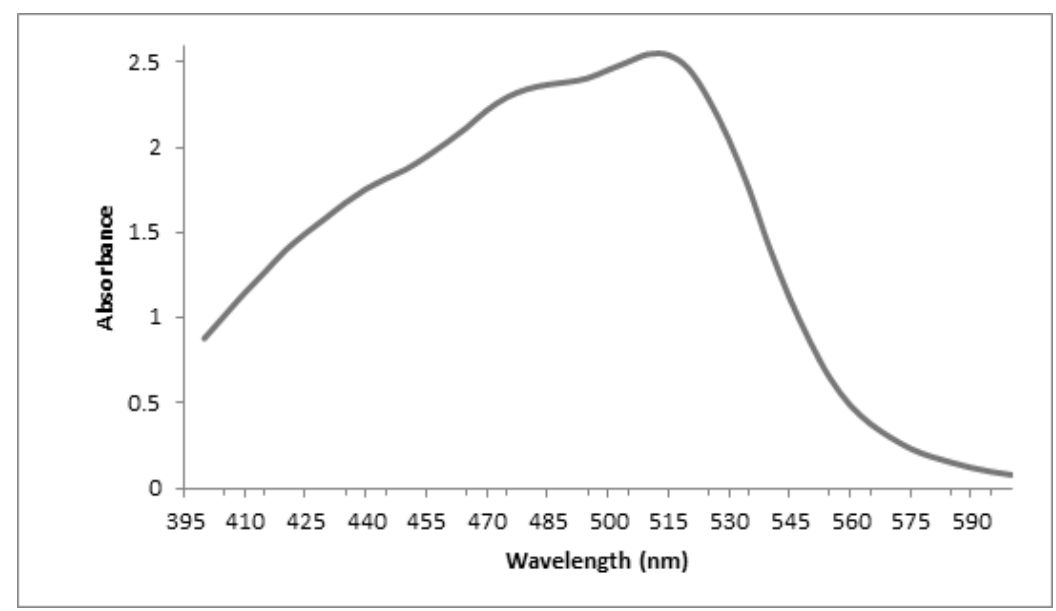

Fig. 1. Absorption spectrum of ferroin indicator solution.

The absorption spectrum of the oxidized form of ferroin $\left(2.5 \times 10^{-3} \mathrm{M}\right.$ blue colored solution of iron $\amalg$ complex) was scanned against distilled water as a blank in the wave length range $400-765 \mathrm{~nm}$. The data are represented in Fig. 2. It is clear from these results that, the indicator exhibits $\lambda$ max at $590 \mathrm{~nm}(\varepsilon=638.8$ $\left.\mathrm{Lmol}^{-1} \mathrm{~cm}^{-1}\right)$. 


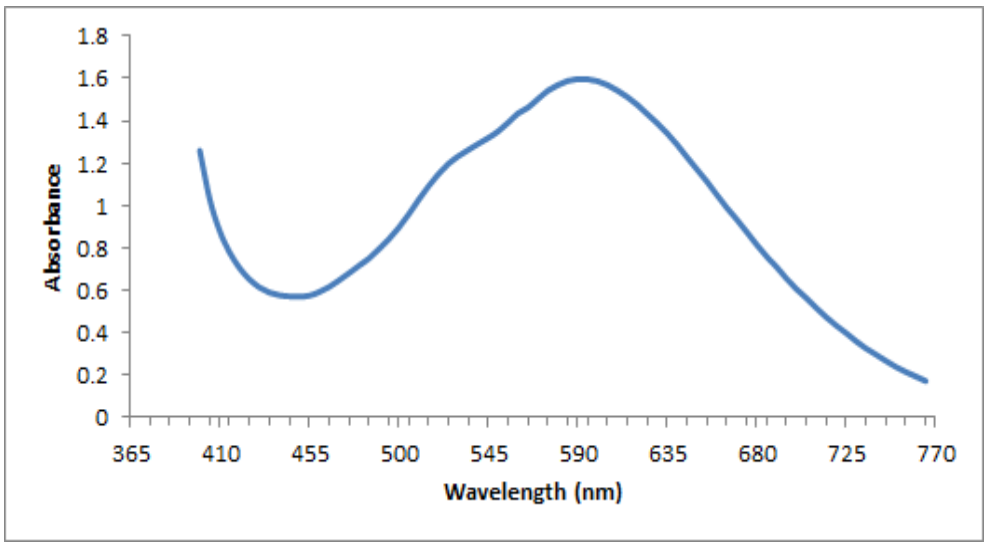

Fig.2. Absorption spectrum of ferroin solution (iron III sulfate complex) .

Study of the reaction between Trp and ferroin indicator in different forms

Effect of time on ferroin (III) spectra

The effect of time on the stability of the oxidized form of ferroin $\left(2.5 \times 10^{-3} \mathrm{M}\right.$ blue solution) is studied carefully and the data obtained are shown in Table 3 and illustrated in Fig. 3. It is obvious from these results that, the absorbance of this indicator at $\lambda_{\max }=590 \mathrm{~nm}$ (of the blue color) decreases within $2 \mathrm{hr}$ after which a constant absorbance is attained.

TABLE 3. Effect of time on the stability of the oxidized ferroin at $\lambda \max =590 \mathbf{n m}$.

\begin{tabular}{|c|c|}
\hline Absorbance & Time (min) \\
\hline 1.597 & 0 \\
\hline 1.401 & 5 \\
\hline 1.179 & 15 \\
\hline 0.983 & 30 \\
\hline 0.806 & 45 \\
\hline 0.648 & 60 \\
\hline 0.513 & 75 \\
\hline 0.398 & 90 \\
\hline 0.304 & 105 \\
\hline 0.242 & 120 \\
\hline 0.231 & 135 \\
\hline 0.23 & 150 \\
\hline 0.229 & 165 \\
\hline 0.229 & 180 \\
\hline
\end{tabular}




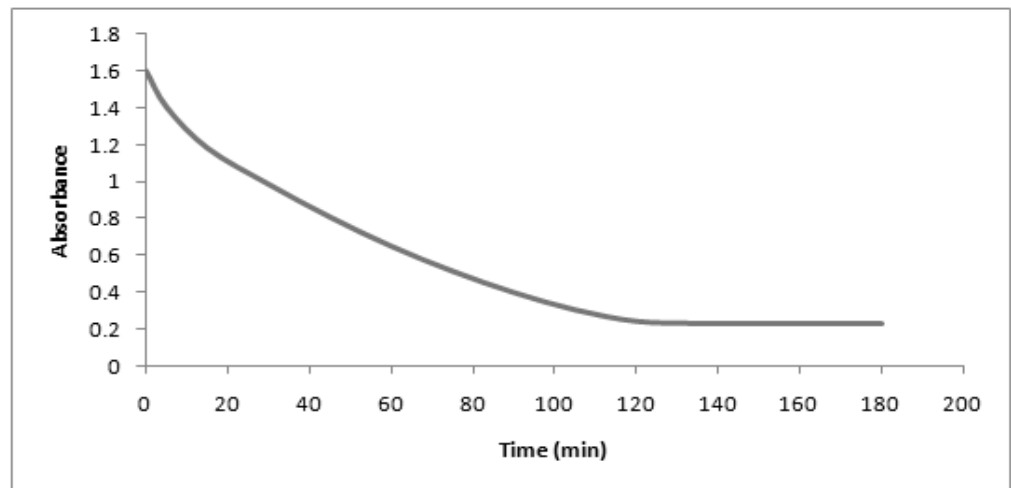

Fig. 3. Effect of time on the stability of the oxidized ferroin at $\lambda \max =590 \mathrm{~nm}$.

It is expected from these results that, ferroin (III) indicator is completely changed at a long time, more than $3 \mathrm{hr}$, into ferroin (II) form. This also means that ferroin (III) indicator obtained by reaction of ferroin (II) with permanganate in sulfuric acid medium is stable at normal temperature but is affected by time factor. To illustrate this conclusion; the absorption spectrum of the same solution after 10 folds dilution $\left(2.5 \times 10^{-4} \mathrm{M}\right)$ was scanned in the same wavelength region. The results obtained are shown in Fig.4. It gives a $\lambda \max =515 \mathrm{~nm}$ with $\varepsilon=$ $1.664 \times 10^{3} \mathrm{Lmol}^{-1} \mathrm{~cm}^{1}$.

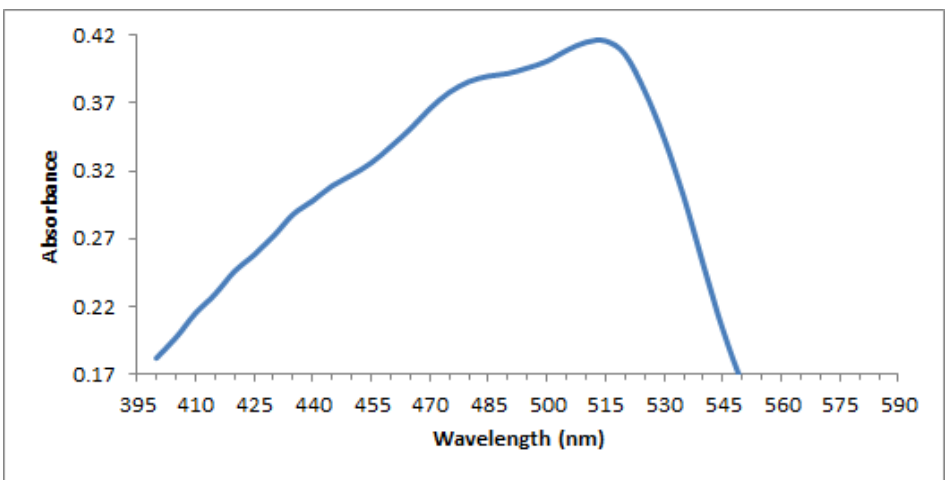

Fig. 4. Absorption spectrum of the oxidized ferroin solution after $3 \mathrm{hr}$ from the beginning of the oxidation reaction.

From these data it is clear that, these results are matching with the previous data of absorption spectrum of $2.5 \times 10^{-4} \mathrm{M}$ ferroin (II) in the reduced form.

Selection of the suitable wavelength $\left(\lambda_{\max }\right)$ of reaction between Trp and ferroin (III) indicator in sulfuric acid medium

The absorption spectrum of ferroin (III)-Trp reaction was scanned in the wavelength range $400-570 \mathrm{~nm}$ (Fig. 5). It is clear from these data that, Trp instantaneously reduces ferroin (III) of blue color $\left(\lambda_{\max }=590 \mathrm{~nm}\right)$ into ferroin (II) red color of $\lambda_{\max }=515 \mathrm{~nm}$.

Egypt. J. Chem. 58, No. 3 (2015) 


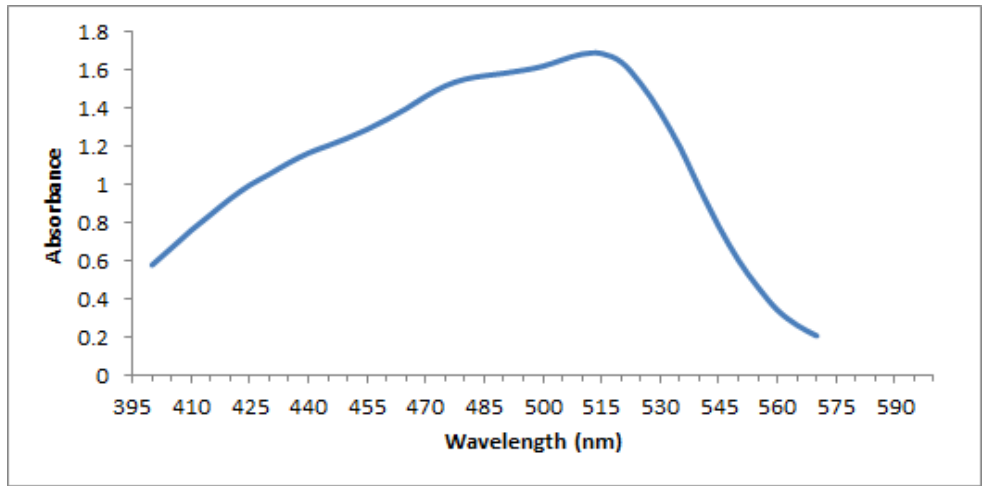

Fig. 5. Absorption spectrum of ferroin-Trp ion pair.

The value of $\lambda_{\max }$ of the reaction product is the same as that of ferroin (II) itself which means that the reaction proceeds via the reduction of ferroin (III) into its reduced form as given by the following proposed mechanism:
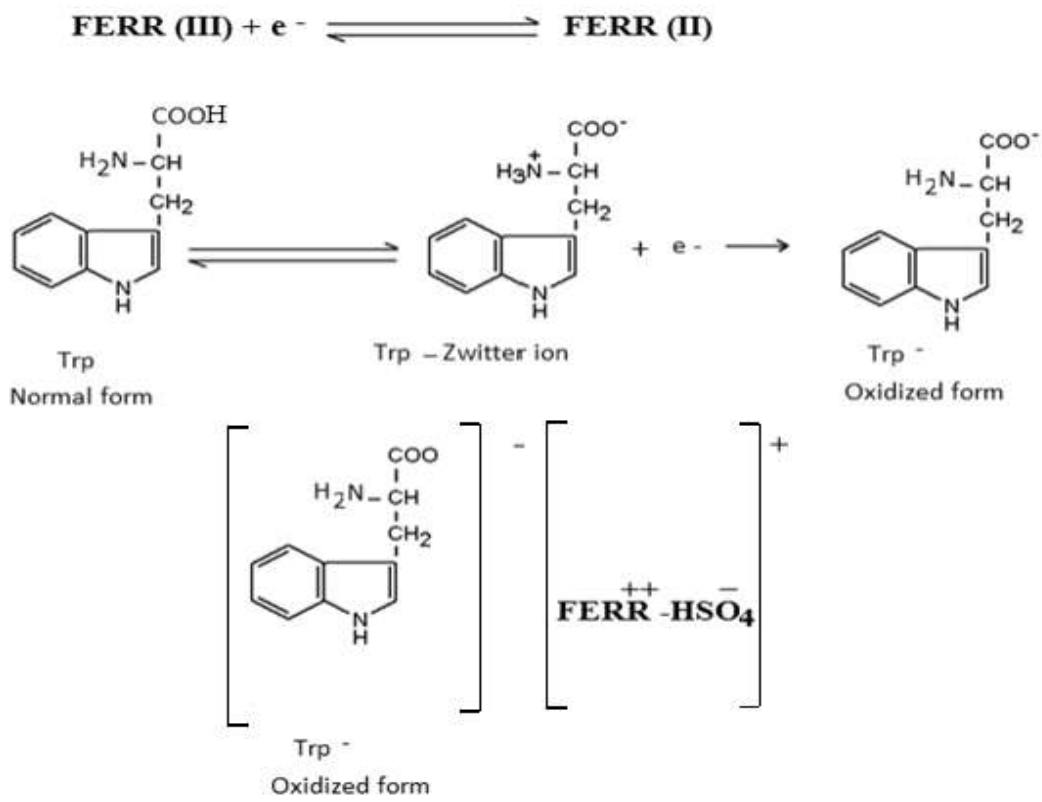

Scheme 1. Redox reaction of Trp-Ferroin (III).

The stoichiometric ratio of this reaction $(1: 1)$ as given by the proposed mechanism needs further study. It is also deduced from the above data that, there is another possible way of reaction between ferroin (II) reduced form and Trp in oxidized form; which needs more research study. 
This mechanism is also confirmed by the decrease of ferroin (III) absorbance at $\lambda_{\max }=590 \mathrm{~nm}$ with the increase of Trp concentration as a result of the proposed reduction process (Fig. 6).

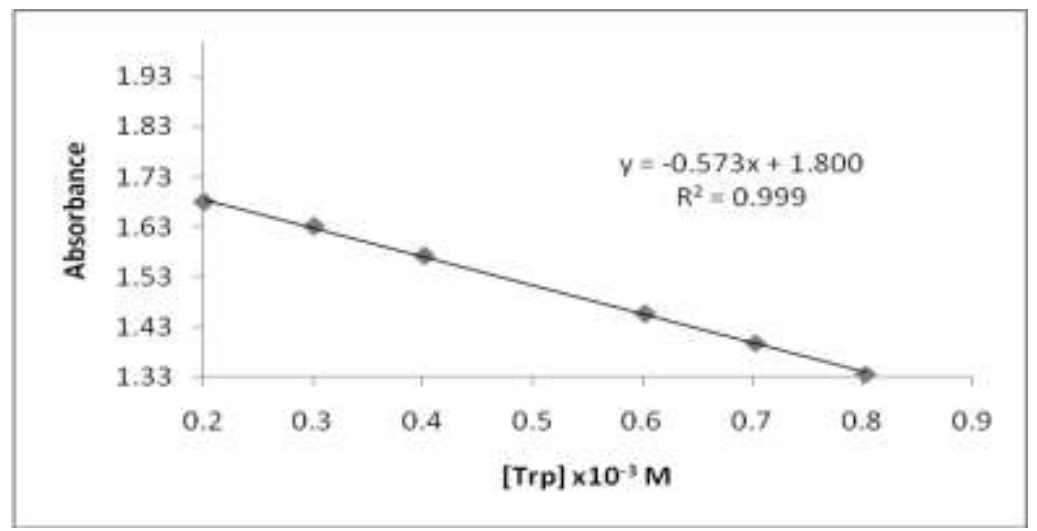

Fig. 6. Linear relation between absorbance - Trp concentration at $\lambda_{\max }=590 \mathrm{~nm}$.

Therefore, this descending calibration curve can be used for microdetermination of Trp in its pure form using ferroin (III) indicator. It was noticed that when these samples were measured at $\lambda_{\max }=515 \mathrm{~nm}$ of ferroin (II); it gives ascending calibration curve. This means that, the reaction between ferroin (II) and Trp in oxidized form takes place by another mechanism; it needs further conformational studies. This conclusion is confirmed by direct reaction between ferroin (II) and Trp in its initial form. In this study, the absorbance of ferroin (II) and variable concentrations of Trp in its initial form; that measured at $\lambda_{\max }=$ $515 \mathrm{~nm}$ which gives a straight line (Fig. 7).

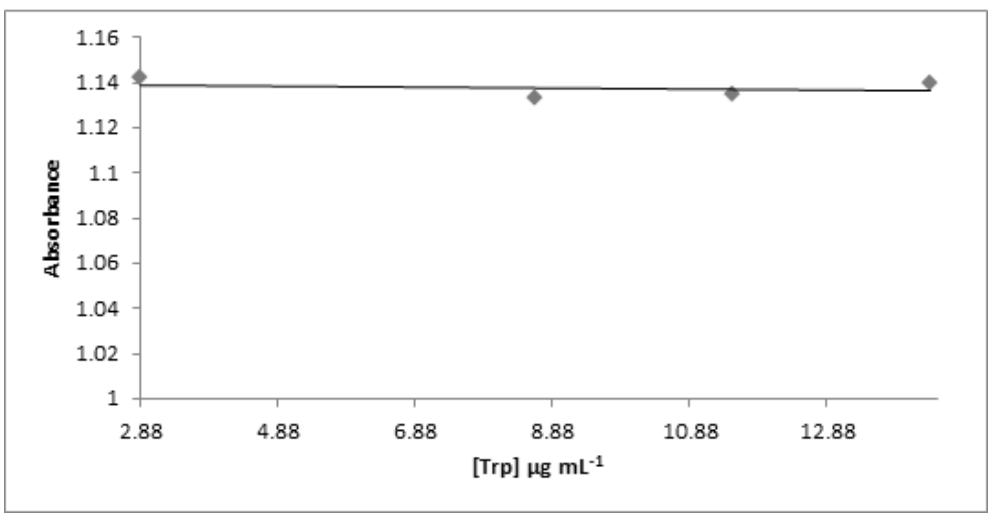

Fig. 7. The effect of variable [normal Trp] on the spectrum of ferroin (II)-Trp at $\lambda_{\max }=515 \mathrm{~nm}$.

Egypt. J. Chem. 58, No. 3 (2015) 
These results means that, there is no direct reaction between ferroin (II) and Trp in its initial form; but the reaction actually goes through binding between this indicator in its reduced form and Trp in its oxidized form. Therefore, this reaction needs further study.

\section{Stoichiometry of the reaction between ferroin (III) and Trp}

The stoichiometric ratio of reduction of ferroin (III) to Trp was determined by using the molar ratio method. The data obtained are shown in and Fig. 8. These results indicate that a 1:1 [ferroin (III)]: [Trp] ratio is formed through the binding between the formed ferroin (II) and Trp oxidized form (Scheme 1).

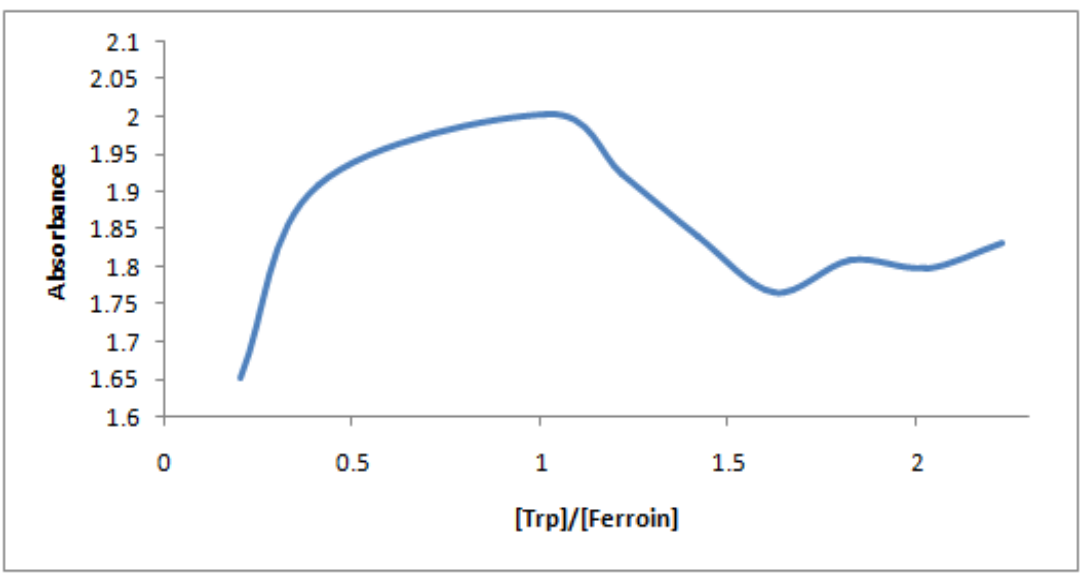

Fig. 8. Stoichiometric ratio of the reaction of ferroin (III) with $\operatorname{Trp}$ at $\lambda \max =515 \mathrm{~nm}$ using molar ratio method.

During the follow of reaction between ferroin (II) and Trp in its oxidized form; it was noticed that, the red color of the reaction product fades with time. Therefore, it is important to study the effect of time on this product.

Effect of time on reaction between ferroin (II) and Trp in its oxidized form

The data obtained on studying the effect of time on reaction between ferroin (II) and Trp in its oxidized form are illustrated in Fig. 9. It is obvious from these data that the absorbance of the product decreases gradually with time until 135 min; where a constant minimum absorbance is attained. This can be explained by the conversion of Trp from oxidized form into normal form by time. This confirms the above conclusion that, no direct reaction between ferroin (II) and Trp in its initial form. This conclusion is also inferred by carrying out the complete run of $1 \times 10^{-4} \mathrm{M}$ of the same solution which shows no $\lambda_{\max }$. This means that, there is no detection of the product between ferroin (II) and Trp in its initial form in the visible region. 


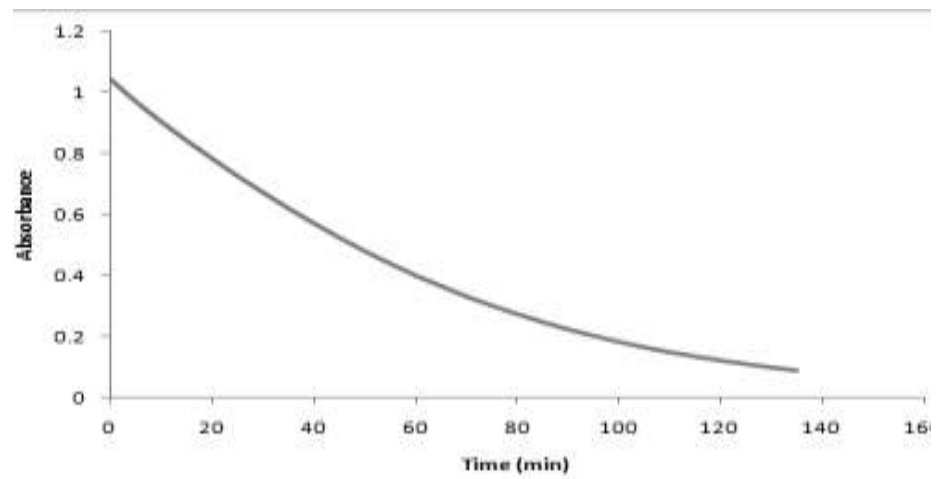

Fig. 9. Effect of time on the ion-pair formation between ferroin (III) and $\operatorname{Trp}$ at $\lambda_{\max }=$ $515 \mathrm{~nm}$.

Therefore, we tried to measure the same solution in the UV region after dilution (Fig. 10).

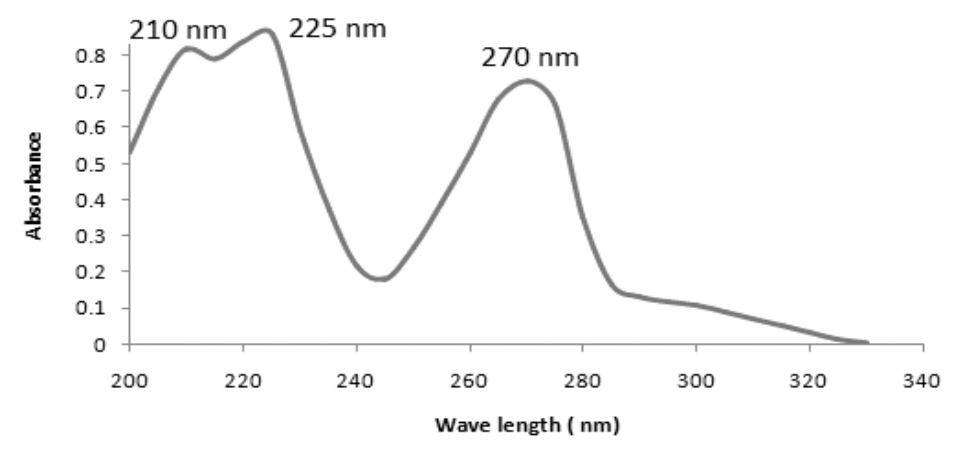

Fig. 10. The UV absorption spectrum of the ferroin (II)-Trp oxidized form product $\left(1 \times 10^{-5} \mathrm{M}\right)$ at $135 \mathrm{~min}$.

To investigate if the product was dissociated forming the original ferroin reacted, absorption spectrum of ferroin of the same concentration was scanned in the same wave length region (Fig. 11).

It is clear from the above spectral data of ferroin (II) - Trp (Fig 10), ferroin (II) (Fig. 11) and Trp in its normal form (Fig.12) that, the only reaction proceeds between ferroin (III), ferroin (II) and Trp in its oxidized form. Also, the reaction between ferroin (II) and Trp in its normal form does not completely proceed. From the above detailed studies; it is possible to use ferroin (III) indicator in micro-determination of Trp in pure and in embryo culture medium, in two different cases. These cases are, the use of blue ferroin in sulfuric acid medium at $\lambda_{\max }=590$ and $515 \mathrm{~nm}$.

Egypt. J. Chem. 58, No. 3 (2015) 


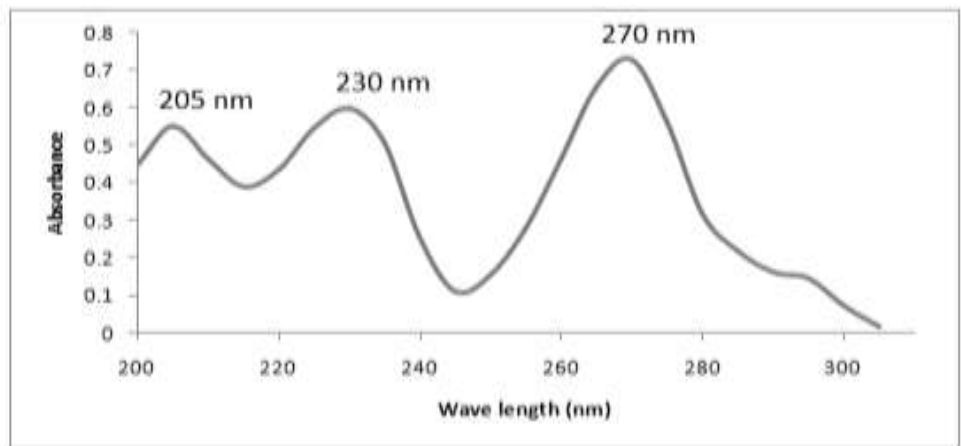

Fig. 11. Absorption spectrum of ferroin $\left(1 \times 10^{-5} \mathrm{M}\right)$.

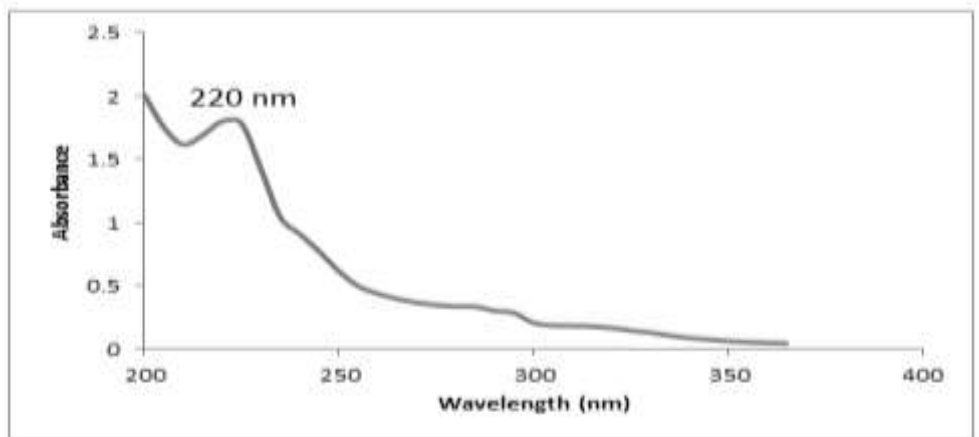

Fig. 12. Spectrum of $1.004 \times 10^{-4} \mathrm{M}$ Trp in $0.3024 \mathrm{~N} \mathrm{H}_{2} \mathrm{SO}_{4}$ medium.

Microdetermination of Trp in pure and in embryo culture medium at $\lambda_{\max }=590$ and $515 \mathrm{~nm}$

The calibration curve of standard Trp at $\lambda_{\max }=590 \mathrm{~nm}$

The reaction between ferroin (III) and Trp at $\lambda_{\max }=590 \mathrm{~nm}$ gives a descending calibration curve in the concentration range 41.058-164.2 $\mu \mathrm{gmL}^{-1}$ (Fig.13); which can be used for micro-determination of Trp in pure form (Table 4).

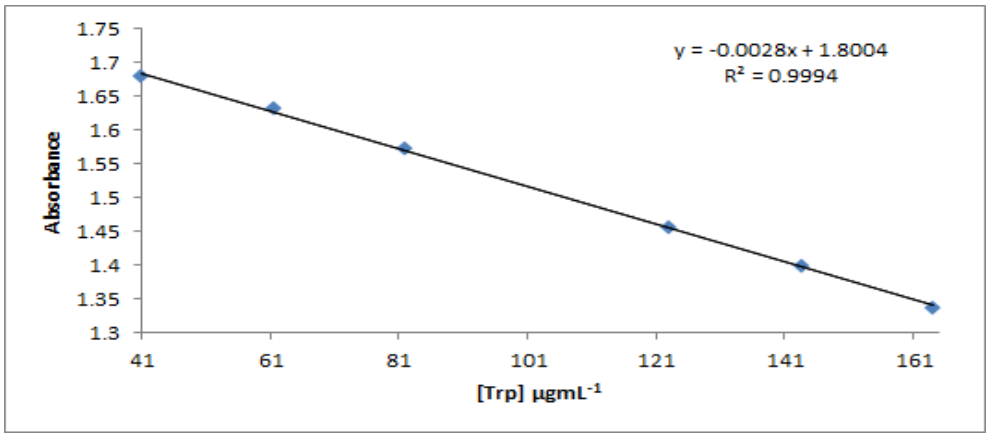

Fig.13. Calibration graph of the reaction between Trp and ferroin (III).

Egypt. J. Chem. 58, No. 3 (2015) 
TABLE 4. Microdetermination of Trp using ferroin (III) at $590 \mathrm{~nm}$.

\begin{tabular}{|c|c|c|c|c|}
\hline $\begin{array}{l}\text { Wt. taken } \\
\text { MgmL }^{-1}\end{array}$ & $\begin{array}{c}\text { Wt. found } \\
\mu \operatorname{gmL}^{-1} \\
(*)\end{array}$ & $\begin{array}{c}\% \text { recovery } \\
(\%)\end{array}$ & SD & $\operatorname{RSD}(\%)$ \\
\hline 41.058 & 41.71 & 101.6 & 0.1350 & 0.3226 \\
\hline 61.59 & 60.15 & 97.66 & 0.0115 & 0.019 \\
\hline 82.12 & 81.15 & 98.82 & 0.0874 & 0.1077 \\
\hline 123.2 & 122.4 & 99.38 & 0.2517 & 0.2056 \\
\hline 143.7 & 143.1 & 99.57 & 0.0577 & 0.0403 \\
\hline 164.2 & 165.1 & 100.6 & 0.2517 & 0.1526 \\
\hline
\end{tabular}

(*) are the means value of five replicates

These data refer to the high accuracy and precision of the applied procedure in determination of standard Trp by using ferroin (III) under proper conditions in the concentration range $41.058-164.2 \mu \mathrm{gmL}^{-1}$; which is confirmed by the values of $\%$ recovery $=97.66-101.6, S D=0.011547-0.2517$ and $\mathrm{RSD}=0.01526-$ $0.3226 \%$.

Table 5 shows the different analytical parameters obtained such as slope, intercept, correlation coefficient, Sandell's sensitivity, molar absorptivity $(\varepsilon)$, standard deviation, limit of quantification, limit of detection and relative standard deviation.

TABLE 5. Analytical parameters for the determination of Trp by the proposed method using ferroin indicator reagent $\lambda_{\max }=590 \mathrm{~nm}$.

\begin{tabular}{|l|c|}
\hline Analytical parameter & Value \\
\hline$\lambda \max (\mathrm{nm})$ & 590 \\
\hline$[\mathrm{Trp}] \mu \mathrm{gmL}^{-1}$ & $41.058-164.2$ \\
\hline$\varepsilon\left(\mathrm{Lmol}^{-1} \mathrm{~cm}^{-1}\right)$ & $0.573 \times 103$ \\
\hline$\% \operatorname{Recovery}(\%)$ & $97.66-101.6 \%$ \\
\hline $\mathrm{SD}$ & $0.0115-0.2517$ \\
\hline $\mathrm{RSD}(\%)$ & $0.0153-0.3226$ \\
\hline $\mathrm{LOD}\left(\mu \mathrm{g} \mathrm{mL}^{-1}\right)$ & 0.7775 \\
\hline $\mathrm{LOQ}\left(\mu \mathrm{g} \mathrm{mL}^{-1}\right)$ & 2.356 \\
\hline & \\
$\mathrm{Y}=\mathrm{a} \mathrm{X}+\mathrm{b}$, & \\
$\mathrm{a}$ & -0.573 \\
$\mathrm{a}$ & 1.800 \\
$\mathrm{R}^{2}$ & 0.999 \\
& \\
\hline $\mathrm{S}\left(\mu \mathrm{g} \mathrm{cm}{ }^{-2}\right)$ & $1.745 \times 10^{-6}$ \\
\hline
\end{tabular}

The small value of Sandell sensitivity indicates the high accuracy of the proposed method in the determination of the standard Trp using ferroin (III) and proper conditions at $\lambda_{\max }=590 \mathrm{~nm}$.

Egypt. J. Chem. 58, No. 3 (2015) 
Validity of beer's law of reaction between standard Trp in its oxidized form and ferroin (II) at $\lambda_{\max }=515 \mathrm{~nm}$

The reaction between standard Trp in its oxidized form and ferroin (II) at $\lambda_{\max }=515 \mathrm{~nm}$ gives an ascending rectilinear line (Fig. 14) in the concentration range $2.05997-12.3598 \mu \mathrm{gmL}^{-1}$ (Table 6). This ascending behavior may be related to the formation of a reaction product of a pronounced stability between ferroin (II) and Trp in its oxidized form which increases with the increase of Trp (Scheme 1).

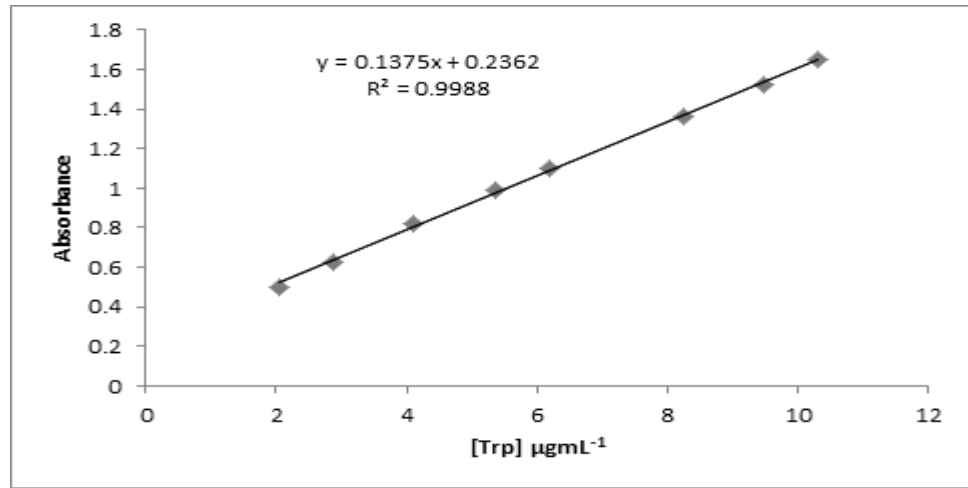

Fig.14. Calibration graph of the reaction between Trp in its oxidized form and Ferroin (II) at $\lambda_{\max }=515 \mathrm{~nm}$.

TABLE 6. Microdetermination of Trp in its oxidized form via reaction with ferroin (II) at $\lambda_{\max }=515 \mathrm{~nm}$.

\begin{tabular}{|l|c|c|c|c|}
\hline $\begin{array}{l}\text { Weight taken of } \\
\text { Trp }\left(\boldsymbol{\mu g m L}^{\mathbf{1}}\right)\end{array}$ & $\begin{array}{c}\text { Weight found of Trp } \\
\left(\boldsymbol{\mu g m L}^{-\mathbf{1}}\right)\end{array}$ & $\begin{array}{c}\text { \% recovery } \\
(\boldsymbol{\%})\end{array}$ & SD & $\begin{array}{c}\text { RSD } \\
(\boldsymbol{\%})\end{array}$ \\
\hline 2.060 & 1.942 & 94.29 & 0.0088 & 0.5348 \\
\hline 2.884 & 2.848 & 98.76 & 0.0092 & 0.3404 \\
\hline 4.120 & 4.254 & 103.3 & 0.0115 & 0.2597 \\
\hline 5.356 & 5.479 & 102.3 & 0.0055 & 0.0942 \\
\hline 6.180 & 6.312 & 102.1 & 0.0060 & 0.0944 \\
8.240 & 8.204 & 99.56 & 0.0161 & 0.2013 \\
\hline 9.476 & 9.356 & 98.74 & 0.0050 & 0.0533 \\
\hline 10.300 & 10.31 & 100.1 & 0.0076 & 0.0721 \\
\hline 12.360 & 12.45 & 100.7 & 0.0058 & 0.0472 \\
\hline
\end{tabular}

Table 7 shows the different analytical parameters obtained such as slope, intercept, correlation coefficient, Sandell's sensitivity, molar absorptivity $(\varepsilon)$, standard deviation, limit of quantification, limit of detection and relative standard deviation . 
TABLE 7. Analytical parameters for the determination of Trp by the proposed method using ferroin indicator reagent at $\lambda_{\max }=515 \mathrm{~nm}$.

\begin{tabular}{|l|c|}
\hline Analytical parameter & value \\
\hline$\lambda \max (\mathrm{nm})$ & 515 \\
\hline$[\operatorname{Trp}] \mu \mathrm{gmL}^{-1}$ & $2.0600-12.36$ \\
\hline$\varepsilon\left(\mathrm{Lmol}^{-1} \mathrm{~cm}^{-1}\right)$ & $0.2818 \times 10^{5}$ \\
\hline$\%$ Recovery & $94.29-103.3 \%$ \\
\hline $\mathrm{SD}$ & $0.0050-0.01612$ \\
$\mathrm{RSD}(\%)$ & $0.0472-0.5348$ \\
\hline $\mathrm{LOD}\left(\mu \mathrm{g} \mathrm{mL}^{-1}\right)$ & 0.1041 \\
\hline $\mathrm{LOQ}\left(\mu \mathrm{g} \mathrm{mL}^{-1}\right)$ & 0.0315 \\
\hline $\mathrm{S}\left(\mu \mathrm{g} \mathrm{cm}^{-2}\right)$ & $3.549 \times 10^{-8}$ \\
\hline
\end{tabular}

The small value of Sandell sensitivity $\left(3.549 \times 10^{-5} \mu \mathrm{g} \mathrm{cm}^{-2}\right)$ indicates the high accuracy of the proposed method in the determination of the Trp. Five replicated measurements is performed at different concentrations of Trp. The standard deviation (0.002449-0.007587) and relative standard deviation values $(0.1398-0.8474 \%)$ indicate the high accuracy and precision of the proposed spectrophotometric method used for determination of Trp using ferroin (III) indicator at $\lambda_{\max }=515 \mathrm{~nm}$.

Before going to apply ferroin (III) indicator in micro-determination of Trp in actual embryo medium we have to check the accuracy of the proposed procedure on its application to analysis of synthetic embryo medium and possible interference due to the presence of other components.

Interference study of embryo's culture medium constituents on the accuracy of the proposed procedure for determination of Trp

1 - First case at $\lambda_{\max }=590 \mathrm{~nm}$ : Before going to apply ferroin indicator in its forms (II and III) for micro-determination of Trp as an essential amino acid in actual embryo media; it was applied on a synthetic medium at two different wavelengths $\lambda_{\max }=590$ and $515 \mathrm{~nm}$, respectively. Table 6 represents the equimolar concentrations of the synthetic medium constituents such as, glucose, sodium pyruvate, Trp, Gly, sodium bicarbonate and potassium chloride; in order to test interference possibility of other constituents to Trp micro-determination at $\lambda_{\max }=590 \mathrm{~nm}$ under proper conditions .

TABLE 8. The composition and concentration of the equimolar synthetic mixture used for the interference study at $\lambda_{\max }=590 \mathrm{~nm}$.

\begin{tabular}{|l|c|}
\hline Component & $\begin{array}{c}\text { Concentration } \\
\mathbf{X 1 0}^{-3} \mathbf{M}\end{array}$ \\
\hline Trp & 4.315 \\
\hline $\mathrm{NaHCO}$ & 4.257 \\
\hline Gly & 4.034 \\
\hline Sodium pyruvate & 4.111 \\
\hline glucose & 4.041 \\
\hline $\mathrm{KCl}$ & 4.469 \\
\hline
\end{tabular}

Egypt. J. Chem. 58, No. 3 (2015) 
Therefore; it is possible to do the micro-determination of Trp in a synthetic mixture (Table 8 ) by measuring the absorbance of the product of its reaction with ferroin (III) at $\lambda_{\max }=590 \mathrm{~nm}$. The obtained results are shown in Table 9 using the calibration graph (Fig.15); which represents the effect of interfering constituents of the synthetic mixture on the accuracy of micro-determination on Trp using ferroin (III) indicator in this medium.

TABLE 9. Microdetermination of Trp in the synthetic mixture at $\lambda_{\max }=590 \mathbf{n m}$.

\begin{tabular}{|c|c|c|c|c|}
\hline $\begin{array}{c}\text { Wt. taken } \\
{\left.\text { ( } \text { ggmL }^{-1}\right)}_{17.63}\end{array}$ & $\begin{array}{c}\text { Wt. found } \\
{\left.\text { ( } \mathbf{\mu g m L}^{-1}\right)}_{16.76}\end{array}$ & $\begin{array}{c}\text { \% recovery } \\
(\%) \\
95.07\end{array}$ & $\begin{array}{c}\text { SD } \\
0.0451\end{array}$ & $\begin{array}{c}\text { RSD (\%) } \\
0.2683\end{array}$ \\
\hline 35.25 & 37.44 & 106.2 & 0.2219 & 0.5879 \\
\hline 44.06 & 42.91 & 97.39 & 0.1747 & 0.4076 \\
\hline 70.5 & 71.05 & 100.8 & 0.0231 & 0.0325 \\
\hline 158.6 & 158.5 & 99.9 & 0.2517 & 0.1587 \\
\hline 176.3 & 177.2 & 100.5 & 0.6351 & 0.3592 \\
\hline
\end{tabular}

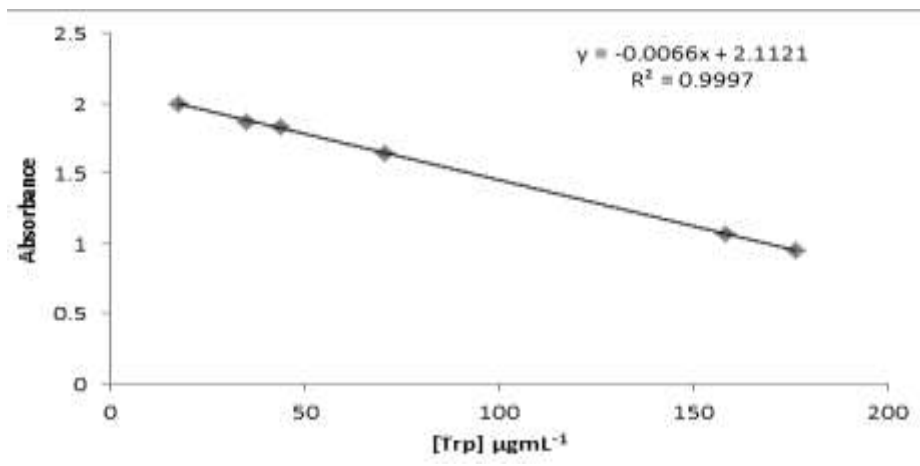

Fig. 15. Microdetermination of $\operatorname{Trp}$ in the synthetic mixture at $\lambda_{\max }=590 \mathrm{~nm}$.

TABLE 10. Analytical parameters for microdetermination of Trp in the synthetic mixture at $\lambda_{\max }=590 \mathrm{~nm}$.

\begin{tabular}{|l|c|}
\hline Analytical parameter & Value \\
\hline$\left[\right.$ Trp] $\mu \mathrm{gmL}^{-1}$ & $17.63-176.3$ \\
\hline$\varepsilon\left(\mathrm{Lmol}^{-1} \mathrm{~cm}^{-1}\right)$ & $0.1347 \times 10^{4}$ \\
\hline$\%$ Recovery & $99.9-100.8$ \\
\hline SD & $0.0231-0.6351$ \\
\hline RSD $(\%)$ & $0.0325-0.5879$ \\
\hline LOD $\left(\mu \mathrm{g} \mathrm{mL}^{-1}\right)$ & 1.103 \\
LOQ $\left(\mu \mathrm{g} \mathrm{mL}^{-1}\right)$ & 47.15 \\
\hline $\left.\mathrm{S}(\mu \mathrm{g} \mathrm{cm})^{-2}\right)$ & $7.424 \times 10^{-7}$ \\
\hline
\end{tabular}


It is clear from these data that, there is no pronounced interfering possibility from other constituents to Trp micro-determination using ferroin (III) at $\lambda_{\max }=590 \mathrm{~nm}$. This conclusion is confirmed by the calculated values of $\mathrm{SD}(0.20306-1.100)$, RSD (0.4838-106360) (and recovery) \% (95.07-106.2 \%) of Trp determination in the given synthetic mixture. These data refer to the high accuracy and precision of the proposed procedure applied for determination of Trp using ferroin (III) indicator in synthetic mixture. This successful application encouraged to apply the proposed procedure for micro-determination of Trp in actual embryo media in presence of other constituents without possible interference at $\lambda_{\max }=590 \mathrm{~nm}$.

2-Second case at $\lambda_{\max }=515 \mathrm{~nm}$ : Table 11 represents the equimolar concentrations of the synthetic medium constituents such as, glucose, sodium pyruvate, Trp, Gly, sodium bicarbonate and potassium chloride ${ }^{(14)}$; in order to test interference possibility of other constituents to Trp micro-determination at $\lambda_{\max }=515$ under proper conditions.

TABLE 11. The composition and concentration of the equimolar synthetic mixture used for the interference study at $\lambda_{\max }=515 \mathrm{~nm}$.

\begin{tabular}{|l|c|}
\hline Component & $\begin{array}{c}\text { Concentration } \\
\mathbf{X 1 0}^{-4} \mathbf{M}\end{array}$ \\
\hline Trp & 2.135 \\
\hline $\mathrm{NaHCO}$ & 2.190 \\
\hline Gly & 2.984 \\
\hline Sodium pyruvate & 2.144 \\
\hline glucose & 2.598 \\
\hline $\mathrm{KCl}$ & 1.985 \\
\hline
\end{tabular}

Therefore; the micro-determination of Trp in a synthetic mixture is possible by measuring the absorbance of the product of its reaction with ferroin (III) at $\lambda_{\max }=515 \mathrm{~nm}$. The obtained results are shown in Table 12 using the calibration graph (Fig. 15); which represents the effect of interfering constituents of the synthetic mixture on the accuracy of micro-determination on Trp using ferroin (II) indicator in this medium.

TABLE 12. Microdetermination of Trp in the synthetic mixture at $\lambda_{\max }=515 \mathrm{~nm}$.

\begin{tabular}{|l|c|c|c|c|}
\hline $\begin{array}{l}\text { Wt. taken of } \\
\text { Trp } \boldsymbol{\mu g m L}^{-\mathbf{1}}\end{array}$ & $\begin{array}{c}\text { Wt. found of Trp } \\
\boldsymbol{\mu g m L}^{-\mathbf{1}}(\boldsymbol{*})\end{array}$ & \% Recovery $(\%)$ & SD & RSD (\%) \\
\hline 2.180 & 2.301 & 105.5 & 0.0116 & 0.5033 \\
\hline 3.052 & 3.056 & 100.1 & 0.0205 & 0.6755 \\
4.360 & 4.136 & 94.86 & 0.0285 & 0.6782 \\
6.541 & 6.503 & 99.42 & 0.0043 & 0.0663 \\
\hline 8.721 & 8.895 & 101.2 & 0.0035 & 0.0395 \\
\hline 10.03 & 9.917 & 96.28 & 0.0226 & 0.2284 \\
\hline 10.90 & 10.81 & 99.11 & 0.0569 & 0.5283 \\
\hline 13.08 & 13.07 & 99.94 & 0.0693 & 0.5269 \\
\hline
\end{tabular}

$\left.{ }^{*}\right)$ Trp] are the means of five replicates.

Egypt. J. Chem. 58, No. 3 (2015) 


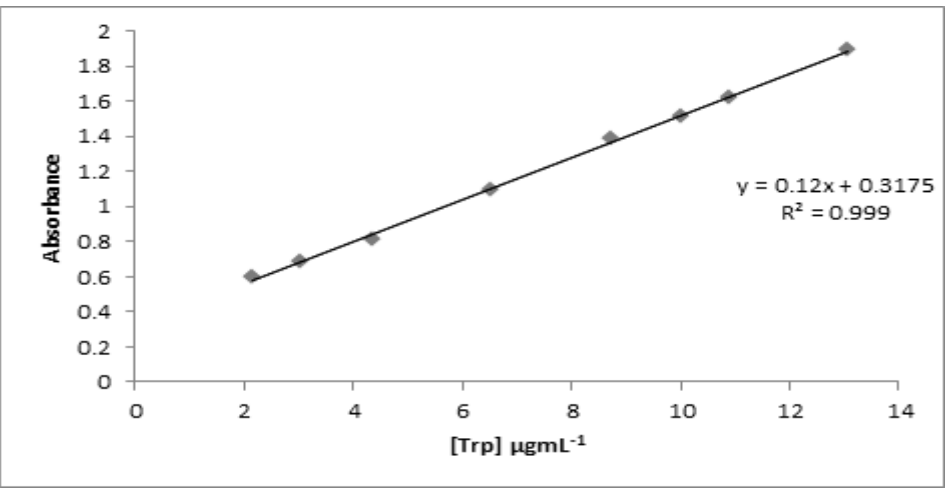

Fig.16. Calibration graph of $\operatorname{Trp}$ in the synthetic mixture using $[$ ferroin III] $=2.0 \times 10$ ${ }^{4} \mathrm{M}$ at $\lambda_{\max }=515 \mathrm{~nm}$.

It is clear from these data that, there is no pronounced interfering possibility from other constituents to Trp micro-determination using ferroin (III) at $\lambda_{\max }=515 \mathrm{~nm}$. This conclusion is confirmed by the calculated values of SD (0.0035-0.0693), RSD (0.0395-0.6782) and recovery \% (94.86-101.2\%) of Trp determination in the given synthetic mixture. These data refer to the high accuracy and precision of the proposed procedure applied for determination of Trp using ferroin (III) indicator in synthetic mixture. This successful application encouraged us to apply the proposed procedure for micro-determination of Trp in actual embryo media in presence of other constituents without possible interference at $\lambda_{\max }=515 \mathrm{~nm}$.

The comparison between data in Tables 13 and 14 refers to the successful application of ferroin indicator in both forms (II and III) in micro-determination of standard Trp in both normal and oxidized forms. Therefore, it is possible to apply this indicator in micro-determination of Trp as an essential amino acid in 0.5 and $1.0 \mathrm{ml}$ embryo's culture media. The data obtained at $\lambda_{\max }=515 \mathrm{~nm}$ are shown in Table 13.

TABLE 13. Microdetermination of Trp in the actual embryo culture medium using

\begin{tabular}{|c|c|c|c|c|c|c|}
\hline $\begin{array}{c}\text { Volume of } \\
\text { medium } \\
\text { taken }(\mathbf{m L})\end{array}$ & $\begin{array}{c}\text { Absorbance } \\
\text { Average }(*)\end{array}$ & $\begin{array}{c}\text { Weight } \\
\text { taken } \\
\boldsymbol{\mu g m L}^{-1}\end{array}$ & $\begin{array}{c}\text { Weight } \\
\text { found } \\
\mathbf{m g m L}^{-\mathbf{1}}(*)\end{array}$ & $\begin{array}{c}\text { \% } \\
\text { recovery } \\
(\boldsymbol{\%})\end{array}$ & SD & $\begin{array}{c}\text { RSD } \\
(\%)\end{array}$ \\
\hline 0.5 & 0.554 & 2.124 & 2.114 & 99.51 & 0.0035 & 0.1640 \\
\hline 1.0 & 0.952 & 5.214 & 5.290 & 101.5 & 0.0196 & 0.3679 \\
\hline
\end{tabular}

(*) is average of five replicates

Wt. taken is calculated from the calibration curve of Trp microdetermination in the pure form at $\lambda_{\max }=515 \mathrm{~nm}$.

Wt. found is calculated from the calibration curve of Trp microdetermination in the synthetic mixture at $\lambda_{\max }=515 \mathrm{~nm}$. 
TABLE 14. Microdetermination of $\operatorname{Trp}$ in the actual embryo culture medium using $2.5 \times 10^{-3} \mathrm{M}$ ferroin as a final concentration at $\lambda_{\max }=590 \mathrm{~nm}$.

\begin{tabular}{|c|c|c|c|c|c|c|}
\hline $\begin{array}{l}\text { No. of } \\
\text { replicates }\end{array}$ & Absorbance & $\begin{array}{c}\text { Weight } \\
\text { taken } \\
\text { MgmL }^{-1}\end{array}$ & $\begin{array}{l}\text { Weight } \\
\text { found } \\
\text { MgmL }^{-1}\end{array}$ & $\begin{array}{c}\% \\
\text { recovery } \\
(\%)\end{array}$ & SD & $\begin{array}{c}\text { RSD } \\
(\%)\end{array}$ \\
\hline 1 & 1.893 & 33.15 & 33.23 & 100.2 & \multirow{6}{*}{0.1793} & \multirow{6}{*}{0.5414} \\
\hline 2 & 1.875 & 32.83 & 32.91 & 100.2 & & \\
\hline 3 & 1.892 & 33.13 & 33.21 & 100.2 & & \\
\hline 4 & 1.854 & 32.47 & 32.55 & 100.3 & & \\
\hline 5 & 1.997 & 34.97 & 35.06 & 100.3 & & \\
\hline 6 & 1.862 & 32.61 & 32.69 & 100.3 & & \\
\hline
\end{tabular}

Volume of culture medium taken $=1.0 \mathrm{ml}$

\section{Conclusion}

These data reveal that the applied method is simple, sensitive, precise and accurate. Also, the reagent utilized in the proposed methods is cheap, readily available and the procedures do not involve any critical reaction conditions or tedious sample preparation. Thus, this proposed spectrophotometric method can be successfully applied for the determination of Trp in the pure form and in embryos' culture medium mixture.

\section{References}

1. Bavister, B.D., Culture of preimplantation embryos: Facts and artifacts. Hum Reprod. Update 1,91(1995).

2. Gardner, D.K. and Lane, M., Amino acids and ammonium regulate mouse embryo development in culture. Biol. Reprod. 48,377 (1993).

3. Gardner, D.K., Mammalian embryo culture in the absence of serum or somatic cell support. Cell. Biol. Int. 18,1163 (1994).

4. Bavister, B.D. and McKiernan, S.H., Regulation of hamster embryo development in vitro by amino acids. In: Bavister BD, (Ed.) Preimplantation Embryo Development. New York: Springer-Verlag, 57(1992).

5. Takahashi, Y. and First, N.L., In vitro development of bovine one-cell embryos: Influence of glucose, lactate, pyruvate, amino acids and vitamins. Theriogenology, 37,963 (1992).

6. Gardner, D.K., Lane, M., Spitzer, A. and Batt, P.A., Enhanced rates of cleavage and development for sheep zygotes cultured to the blastocyst stage in vitro in the absence of serum and somatic cells: Amino acids, vitamins and culturing embryos in groups stimulate development. Biol. Reprod. 50, 390 (1994).

Egypt. J. Chem. 58, No. 3 (2015) 
7. Gardner, D.K. and Lane, M., Alleviation of the '2-cell block' and development to the blastocyst of CF1 mouse embryos: Role of amino acids, EDTA and physical parameters. Hum Reprod. 11, 2703(1996).

8. Dumoulin, J.C., Evers, J.L., Bakker, J.A., Bras, M., Pieters, M.H. and Geraedts J.P., Temporal effects of taurine on mouse preimplantation development in vitro. Hum Reprod. 7, 403 (1992).

9. Dumoulin, J.C., Evers, J.L., Bras, M., Pieters, M.H. and Geraedts, J.P., Positive effect of taurine on preimplantation development of mouse embryos in vitro. J. Reprod Fertil, 94, 373(1992).

10. Bavister, B.D., Studies on the developmental blocks in cultured hamster embryos In: Bavister BD, (Ed.) The Mammalian Preimplantation Embryo. New York: Plenum, 219(1987).

11. Thompson, J.G., Gardner, D.K., Pugh, P.A., McMillan, W.H. and Tervit, H.R., Lamb birth weight is affected by culture system utilized during in vitro pre-elongation development of ovine embryos. Biol Reprod. 53,1385(1995).

12. Sakkas, D., Garden, D.K., Weissman, A., Howles, C. and Shoham, Z. (Ed.), Textbook of Assisted Reproductive Technologies: Laboratory and Clinical Prospectives, Second ed, London: Taylor and Francis, 235-45(2004).

13. Vosburgh, W.C. and Cooper, G.R., J. Am. Chem. Soc. 63, 437 (1941).

14. SAGE Assisted Reproduction Products ${ }^{\mathrm{TM}}$ Catalog. 
دراسة طيفية للتفاعل بين تريبتوفان و فيروين فى صور مختلفه

محمد عبدالجواد زايد و محمد مصطفى طه"

قسم الكيمياء- كلية العلوم- جامعة القاهرة و مُمستشفى ادم الدولى- المهندسين-

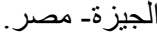

تم تحضير كاثف فيروين لـ لمعايرة فيروين П مع برمنجنات الصوديوم فى الصي

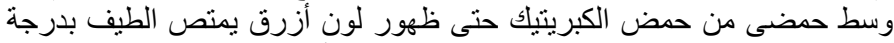

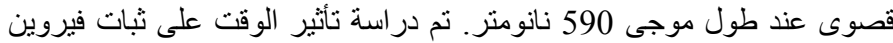

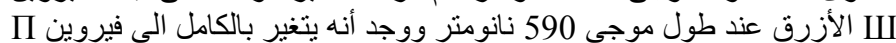

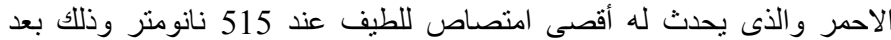
مرور 3 ساعات من تكوينه.

لذلك تمت هذه الدر اسة للتفاعل بين ترييتوفان و فيروين فى صورته المؤكسدة

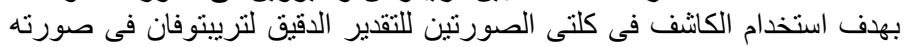

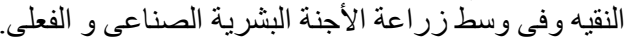

النتائج التى تم الحصول عليها فى هذه الدراسة تعكس دقة الطريقة المستخدمة

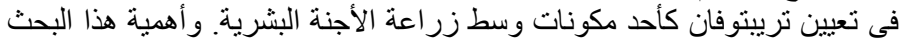

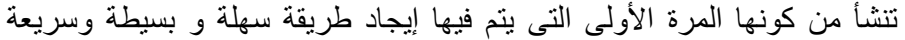
لتقدير ترييتوفان الموجود في وسط زئن زراعة الأجنة البشرية طيفيا ويمكن استخدام

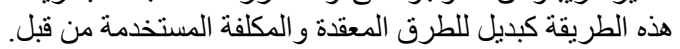

